University of Nebraska - Lincoln

DigitalCommons@University of Nebraska - Lincoln

West Central Research and Extension Center, North Platte

Agricultural Research Division of IANR

1983

\title{
Cerebral Abscess and Cephenemyia phobifer in a Mule Deer in Central Nebraska
}

Jerre L. Johnson

West Central Research and Extension Center, North Platte

John B. Campbell

West Central Research and Extension Center, North Platte

Alan R. Doster

University of Nebraska-Lincoln, adoster1@unl.edu

George Nason

Nebraska Game \& Parks Commission

R. J. Cagne

SEL, USDA, Beltsville

Follow this and additional works at: https://digitalcommons.unl.edu/westcentresext

Part of the Agriculture Commons

Johnson, Jerre L.; Campbell, John B.; Doster, Alan R.; Nason, George; and Cagne, R. J., "Cerebral Abscess and Cephenemyia phobifer in a Mule Deer in Central Nebraska" (1983). West Central Research and Extension Center, North Platte. 10.

https://digitalcommons.unl.edu/westcentresext/10

This Article is brought to you for free and open access by the Agricultural Research Division of IANR at DigitalCommons@University of Nebraska - Lincoln. It has been accepted for inclusion in West Central Research and Extension Center, North Platte by an authorized administrator of DigitalCommons@University of Nebraska Lincoln. 
Journal of Wildlife Diseases, 19(3), 1983, pp. 279-280 (c) Wildlife Disease Association 1983

\section{Cerebral Abscess and Cephenemyia phobifer in a Mule Deer in Central Nebraska}

Jerre L. Johnson, John B. Campbell, University of Nebraska North Platte Station, North Platte, Nebraska 69101 USA; Alan R. Doster, University of Nebraska-Lincoln, Lincoln, Nebraska 68583, USA; George Nason, Game and Parks Commission, North Platte, Nebraska 69101, USA; and R. J. Cagne, Systematic Entomology Laboratory, USDA, Beltsville, Maryland 20705, USA

A wild yearling male mule deer (Odocoileus hemionus hemionus) from south central Ne-

Received for publication 11 June 1982 braska was submitted to the University of Nebraska North Platte Station Diagnostic Laboratory with the history of severe depression, slight incoordination, and visual impairment. Gross examination revealed a large abscess in-

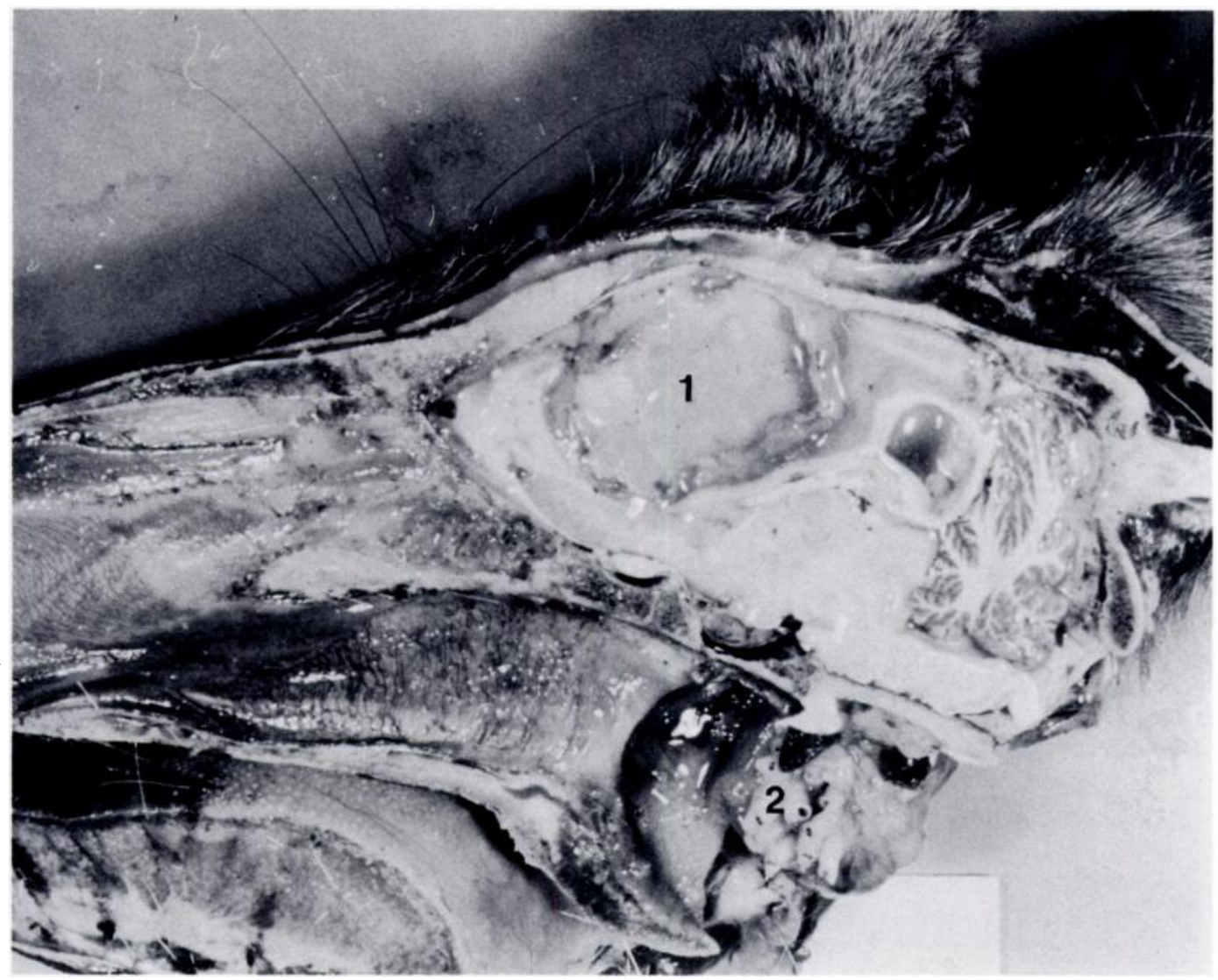

Figure 1. Sagittal section of mule deer head showing large cerebral abscess (1) and bots (Cephenemyia phobifer) in retropharyngeal area (2). 
volving approximately $65-75 \%$ of the cerebral hemispheres of the brain and approximately 30 bots in the retropharyngeal pouches (Fig. 1). No other gross lesions were present.

Bacteriologic examination, utilizing $5 \%$ sheep blood agar, revealed Klebsiella pneumoniae from the kidney, liver, spleen, and cerebral spinal fluids. Cultures of the brain, utilizing $5 \%$ sheep blood agar and chocolate agar, revealed alpha-Streptococcus and Corynebacterium pyogenes. The bots were identified as Cephenemyia phobifer. Representative specimens have been deposited in the L.S. National Parasite Collection in Beltsville, Maryland (Accession No. 77316). No virus was isolated via inoculation of tissue cultures or embryonated chicken eggs.

Utilizing routine histopathologic methods (Luna, 1968, In Manual of Histologic Staining Methods of the Armed Forces Institute of $\mathrm{Pa}$ thology, McGraw-Hill, Inc.. New York, pp. 3239), examination of the brain revealed areas of necrotic debris surrounded by degenerative neutrophils encapsulated by inflammatory cells and connective tissue.
Five species of Cephenemyia have been reported in North America: C. apicata, C. jellisoni, C. phobifer, C. pratti, and C. trompe Cephenemyia pratti is most commonly found in mule deer (Harwood and James, 1979, In Entomology in Human and Animal Health, Macmillan Publishing Co., New York, pp. 311312). Cephenemyia phobifer is usually present in eastern United States and generally is found in white-tailed deer (Odocoileus virginianus virginianus) (Davis and Anderson, 1971, In Parasitic Diseases of Wild Mammals, Iowa State University Press, Ames, Iowa, p. 283).

Cerebral abscesses may arise from septic thromboemboli or bacterial emboli, or by direct invasion of the brain from an adjacent structure. It may be possible that migration of the larvae of $C$. phobifer may play a role in the development of the cerebral abscess. Myiasis producing frontal abscesses with Corynebacterium pyogenes has been reported in sheep and cattle (Jubb and Kennedy, 1970, In Pathology of Domestic Animals, Academic Press, New York and London, p. 402). 